\author{
ANNOUNCEMENTS \\ 2nd WESTERN PACIFIC CONGRESS \\ ON INFECTIOUS DISEASES AND CHEMOTHERAPY \\ December 11-14, 1990 \\ Jomtien-Pattaya, Thailand
}

The programme will include major Symposia and Free Communications (Posters and Oral Presentations) on: Infectious Diseases (including community and hospital acquired, paediatric and adult, surgical, genitourinary and tropical infections); Microbiological Laboratory Techniques; Antimicrobial Chemotherapy; Immunology, Immunotherapy and Vaccines.

Further information from:

Dr P. Jayanetra, EPIDC Secretariat Office, Department of Pathology, Faculty of Medicine,

Ramathibodi Hospital, Rama VI Road, Bangkok 10400, Thailand.

The 162 nd meeting of the

PATHOLOGICAL SOCIETY OF GREAT BRITAIN AND IRELAND will be held at the UNIVERSITY OF CAMBRIDGE on January 3rd-5th, 1991

Microbiology Programme (provisional)

Thursday, January 3rd a.m. Symposium-New aspects of vaccines.

p.m. Posters and free papers.

Friday, January 4th a.m. Symposium-Microbial ecology in mixed populations.

p.m. Posters and free papers.

Further information may be obtained from the Meetings Secretary:

Dr E. Mary Cooke, Central Public Health Laboratory, Division of Hospital Infection, 61 Colindale Avenue, London NE9 5HT.

Tel: 081-200-4400 Ext 4249

\title{
The ROYAL COLLEGE OF PATHOLOGISTS London
}

One-day symposium

"FIT FOR DRINKING, FIT FOR BATHING"-THE MICROBIOLOGICAL SAFETY OF WATER on Wednesday, January 30, 1991

Programme

Morning: Chairman, Professor R. Y. Cartwright (PHLS, Guildford)

The microbiology of drinking water supplies

Dr J. Dadswell (PHLS, Reading)

Drinking water quality monitoring - a practical approach

Dr J. Colbourne (Thames Water Utilities) 
Quality assurance in water biology

Dr N. Lightfoot (PHLS, Newcastle upon Tyne)

Legionella in water systems

Dr C. Bartlett (Communicable Diseases Surveillance Centre)

Management and prevention of pollution in rivers

Dr J. Pentreath (National Rivers Authority)

Afternoon: Chairman, Dr M. J. Lewis (PHLS, Nottingham)

Sewage disposal-making it safe

Dr E. Pike (WRC Medmenham)

Sewage contamination of the sea and beaches

Professor R. Y. Cartwright (PHLS, Guildford)

Monitoring and prevention of contamination of shellfish

Dr D. Lees (MAFF, Weymouth)

Infective hazards of the recreational use of water

Dr R. Stanwell-Smith (Communicable Diseases Surveillance Centre)

Microbiological problems of swimming pools, hydrotherapy and jacuzzis

Dr R. R. Joce (North \& East Herts Health Authority) and Dr M. J. Lewis (PHLS, Nottingham)

Further information and registration forms can be obtained from:

Scientific Meetings Officer,

The Royal College of Pathologists,

2 Carlton House Terrace,

London SW1Y 5AF.

(Tel: 071-930-5861)

ANAEROBES IN THE 90s

The SEVENTH BIENNIAL SYMPOSIUM of the SOCIETY FOR ANAEROBIC MICROBIOLOGY

(formerly the Anaerobe Discussion Group, Ltd)

will be held at CHURCHILL COLLEGE, CAMBRIDGE

on Thursday, July 18th-Saturday, July 20th, 1991

\section{Programme}

Thursday, July 18 th $\quad$ p.m. Anaerobes in clinical practice.

Friday, July 19th SAM Dinner.

a.m. Toxins of anaerobic bacteria. Anaerobes in intestinal physiology.

p.m. Environmental and ecological aspects of anaerobes.

Poster session.

Reception and trade exhibition.

Saturday, July 20th a.m. Recent changes in taxonomy of non-sporing anaerobes.

Each session will include keynote presentations, free papers and discussion.

Contributions are invited for the free papers and for the open poster session.

Further information and registration forms may be obtained from:

Conference Contact,

42 Devonshire Road,

Cambridge, CB1 2BL.

(Tel: 0223-323437, Fax: 0223-460396) 